\title{
Structural and Raman Spectroscopic Study of Antimony Doped $\mathrm{Bi}_{0.5} \mathrm{Na}_{0.5} \mathrm{TiO}_{3}$ Electroceramic
}

\author{
K. N. Singh ${ }^{*}$, Versha Sao ${ }^{1}$, P. Tamrakar ${ }^{1}$, S. Soni ${ }^{1}$, V. K. Dubey ${ }^{2}$, P. K. Bajpai ${ }^{3}$ \\ ${ }^{1}$ Department of Physics, Dr. C. V. Raman University, Bilaspur, India \\ ${ }^{2}$ Department of Physics, Government Science PG College, Bilaspur, India \\ ${ }^{3}$ Advance Materials Research Laboratory, Guru Ghasidas Vishwavidyalaya, Bilaspur, India \\ Email: ${ }^{*}$ knsingh.ggv@gmail.com
}

Received 22 March 2015; accepted 9 August 2015; published 12 August 2015

Copyright (C) 2015 by authors and Scientific Research Publishing Inc.

This work is licensed under the Creative Commons Attribution International License (CC BY). http://creativecommons.org/licenses/by/4.0/

(c) (i) Open Access

\begin{abstract}
Pure and Antimony ( $\mathrm{Sb}, \mathrm{x}=\mathbf{0 . 0 1 \%}, 0.02 \%$ and $0.03 \%$ ) doped $\mathrm{Bi}_{0.5} \mathrm{Na}_{0.5} \mathrm{TiO}_{3}$ electro ceramics were successfully synthesized by a conventional solid state reaction route. $X$-ray diffraction analysis showed that a distinct $002 / 200$ peak splitting appears when doping percentage changes from 0.02 to $\mathbf{0 . 0 3}$, referring to a hexagonal symmetry. The data show the Lorentzian deconvolution of the 002 and 200 peaks of the tetragonal phase and the 202 peak of the rhombohedral phase. There is no significant change in the Raman spectra for the prepared compositions while some additional peaks around 151, 281, 585 and $853 \mathrm{~cm}^{-1}$ compared to the peaks observed in BNT. It may be possible that a morphotrophic phase boundary (MPB) exists around $x=0.03$. Analysis of peak positions, widths and intensities of Raman spectroscopy study also confirmed the existence of structural change around $x=0.03$ composition.
\end{abstract}

\section{Keywords}

Ceramics, X-Ray Diffraction, Raman Spectroscopy

\section{Introduction}

The ferroelectric perovskite-type ceramic materials having general formula $\mathrm{ABO}_{3}$ with different cationic distributions at A/B-sites are being investigated due to their important device applications such as in capacitors, piezoelectric ultrasonic transducers, electrostrictive actuators, SAW substrates, etc. [1]-[3]. The doping or composi-

\footnotetext{
${ }^{*}$ Corresponding author.
}

How to cite this paper: Singh, K.N., Sao, V., Tamrakar, P., Soni, S., Dubey, V.K. and Bajpai, P.K. (2015) Structural and Raman Spectroscopic Study of Antimony Doped $\mathrm{Bi}_{0.5} \mathrm{Na}_{0.5} \mathrm{TiO}_{3}$ Electroceramic. Journal of Materials Science and Chemical Engineering, 3, 43-49. http://dx.doi.org/10.4236/msce.2015.38007 
tional changes in these ceramics can control the high electromechanical characteristics. Bismuth sodium titanate, $\mathrm{Bi}_{0.5} \mathrm{Na}_{0.5} \mathrm{TiO}_{3}$ (BNT) [4] is one of the important ferroelectrics among the lead-free piezoelectric materials with large remnant polarization $\left(P_{\mathrm{r}}=38 \mu \mathrm{C} / \mathrm{cm}^{2}\right)$, high Curie temperature $\left(T_{c}=320^{\circ} \mathrm{C}\right)$, and shows diffuse phase transition (DPT) with perovskite structure. In addition to the DPT, two more phase transitions were reported at $230^{\circ} \mathrm{C}$ and at $500^{\circ} \mathrm{C}-600^{\circ} \mathrm{C}$. It is observed that the coexistence of the cubic and the tetragonal phases in the temperature ranges from $500^{\circ} \mathrm{C}$ to $540^{\circ} \mathrm{C}$, and the tetragonal and the rhombohedral phases from $255^{\circ} \mathrm{C}$ to $400^{\circ} \mathrm{C}$ [5]. Several of its crystal structures, including cubic, tetragonal and rhombohedral, have been studied [6] [7] over different temperature ranges.

Relaxor behaviour of BNT depends on substitution in both A-site and B-site [8] and also it has been observed that the dopants control the phase transitions, electromechanical properties, relaxor behaviour and the piezoelectric coefficients. Many studies have been performed on BNT to understand the effect of dopants on structural and electrical properties of the material. Some studies focus on dielectric properties, while others focus on piezoelectric properties. BNT is a good material for both applications because it can be modified to enhance a specific desirable behaviour. Both A-site and B-site dopants have been studied to determine how they affect the properties of BNT [9]-[14].

Recently, some investigations have been done on the search for the modifications in the BNT-based systems

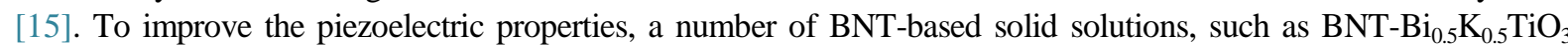
[16], (1 - x - y) $\mathrm{Bi}_{0.5} \mathrm{Na}_{0.5} \mathrm{TiO}_{3}-\mathrm{xB}_{\mathrm{i} .5} \mathrm{~K}_{0.5} \mathrm{TiO}_{3}-\mathrm{yBi}_{0.5} \mathrm{Li}_{0.5} \mathrm{TiO}_{3}$ [17], BNT-NaNbO 3 [18], BNT-Ba-TiO $-\mathrm{Bi}_{0.5} \mathrm{Li}_{0.5} \mathrm{TiO}_{3}$ [19], $\mathrm{Bi}_{0.5} \mathrm{Na}_{0.5} \mathrm{TiO}_{3}-\mathrm{SrTiO}_{3}-\mathrm{Bi}_{0.5} \mathrm{Li}_{0.5} \mathrm{TiO}_{3}$ [20] and $\mathrm{BNT}-\mathrm{Bi}_{0.5} \mathrm{~K}_{0.5} \mathrm{TiO}_{3}-\mathrm{BaTiO}_{3}$ [21], $\mathrm{Bi}_{0.5} \mathrm{Na}_{0.5} \mathrm{TiO}_{3}-\mathrm{Bi}_{0.5} \mathrm{Li}_{0.5} \mathrm{TiO}_{3}$ [22] have been developed and studied intensively [23]. The $\mathrm{Bi}_{0.5} \mathrm{Na}_{0.5} \mathrm{TiO}_{3}$-based piezoelectric substituted by $\mathrm{Ba}^{2+}$ [24] [25] and the effect of $\mathrm{Ba}^{2+}$ in BNT ceramics on dielectric and conductivity properties have been studied [26].

In this report, Raman spectroscopic studies were done on lead-free antimony doped BNT in order to understand the effect of antimony in their local structure and symmetry.

\section{Experimental Procedure}

Antimony (Sb, $\mathrm{x}=0.01 \%, 0.02 \%$ and $0.03 \%$ ) doped $\mathrm{Bi}_{0.5} \mathrm{Na}_{0.5} \mathrm{TiO}_{3}$ compositions were prepared using solid state reaction route. The stoichiometric amount of $\mathrm{Bi}_{2} \mathrm{O}_{3}, \mathrm{Na}_{2} \mathrm{CO}_{3}, \mathrm{TiO}_{2}$ and $\mathrm{SbO}_{2}(>99 \%)$ were mixed in wet medium (acetone) for $4 \mathrm{~h}$. The mixed powders were calcined at $900^{\circ} \mathrm{C}$ for $4 \mathrm{~h}$ by using muffle furnace. Calcined powder were structurally analyzed using X-ray diffraction data which were carried out using X-ray diffractometer with $\mathrm{Cu} \mathrm{K}_{\alpha}(\lambda=1.54056 \AA)$. Fine calcined powder were pressed into cylindrical pellets of $10 \mathrm{~mm}$ diameter and 1 - $2 \mathrm{~mm}$ thickness under an iso-static pressure of $100 \mathrm{MPa}$. Polyvinyl alcohol (PVA) was used as a binder. The pellet were sintered at $950^{\circ} \mathrm{C}$ for 4 hours and cooled down to room temperature. Air dried silver past was used for electroding the pellets.

\section{Results and Discussion}

\subsection{Structural Study}

Figure 1(a) shows the XRD patterns of $\mathrm{Sb}(0.0,0.01,0.02$ and 0.03$)$ doped $\mathrm{Bi}_{0.5} \mathrm{Na}_{0.5} \mathrm{TiO}_{3}$ ceramics sintered at $950^{\circ} \mathrm{C}$ for $4 \mathrm{~h}$. All the compositions exhibit a pure perovskite structure and no second phases are observed, which implies that $\mathrm{Sb}$ ceramic has diffused into the $\mathrm{Bi}_{0.5} \mathrm{Na}_{0.5} \mathrm{TiO}_{3}$ lattices completely. All the reflection peaks of the X-ray profile were indexed and lattice parameters were determined using a least-squares method with the help of a standard computer programme (POWD) [27]. The values of observed $\left(\mathrm{d}_{\mathrm{obs}}\right)$ and calculated $\left(\mathrm{d}_{\mathrm{cal}}\right)$ interplanar spacing, (hkl) indexing and intensity are shown in Table 1. Good agreement between the observed and

Table 1. Lattice parameters of pure BNT and Sb doped BNT samples.

\begin{tabular}{|c|c|c|c|c|}
\hline & BNT (Pure) & $\mathrm{BNT}(\mathrm{Sb}=0.01)$ & $\mathrm{BNT}(\mathrm{Sb}=0.02)$ & $\mathrm{BNT}(\mathrm{Sb}=0.03)$ \\
\hline Lattice Parameter & $\begin{array}{l}a=5.258 \\
c=6.502\end{array}$ & $\begin{array}{l}\mathrm{a}=5.278 \\
\mathrm{c}=6.438\end{array}$ & $\begin{array}{l}\mathrm{a}=5.256 \\
\mathrm{c}=6.538\end{array}$ & $\begin{array}{l}a=5.256 \\
c=6.578\end{array}$ \\
\hline Perovskite Cell Volume & 157.04 & 155.023 & 156.41 & 158.69 \\
\hline Relative Density (\%) & 91 & 94 & 95 & 94.8 \\
\hline
\end{tabular}




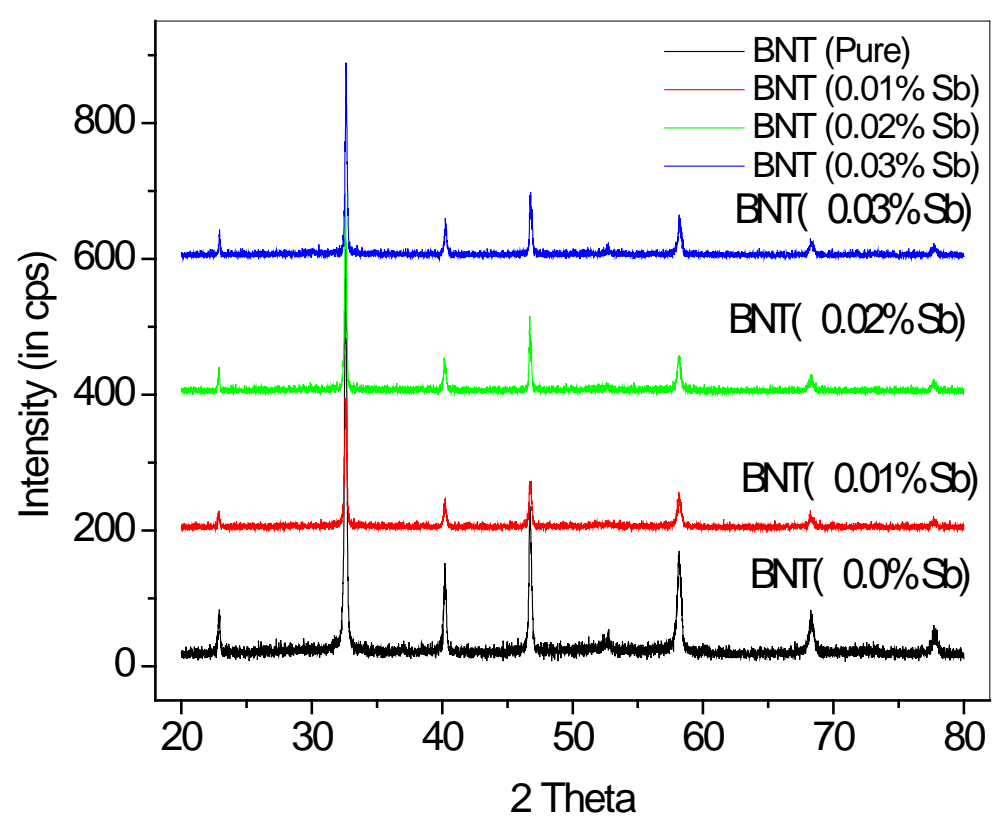

(a)

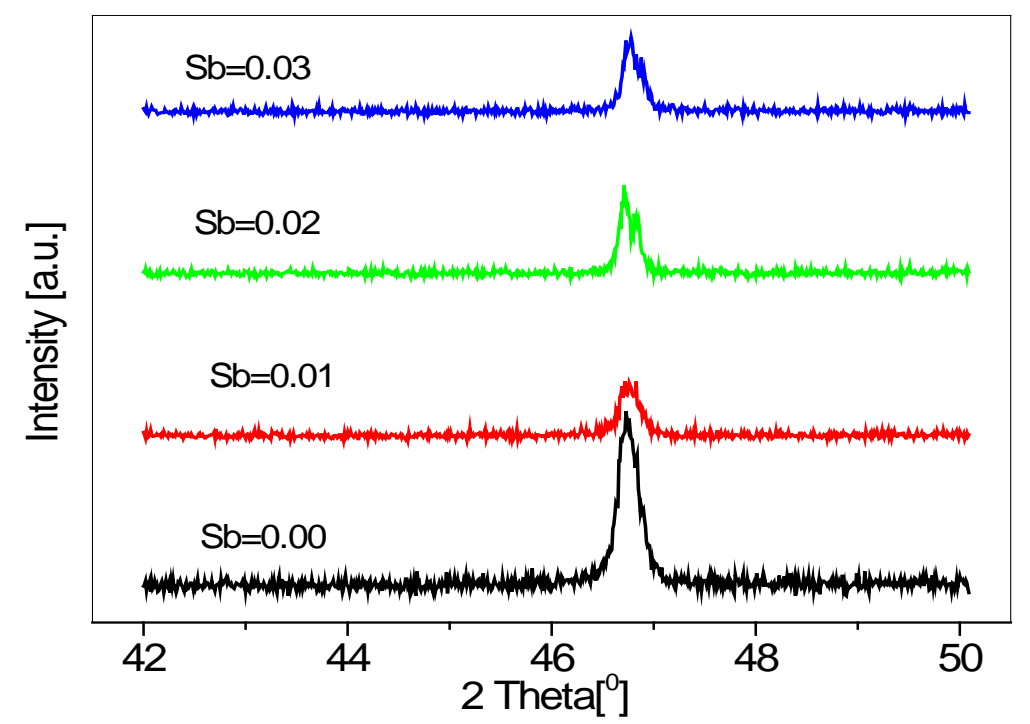

(b)

Figure 1. (a) X-ray diffraction patterns of Sb doped BNT ceramics of different compositions; (b) X-ray diffraction patterns of Sb doped BNT ceramics of different compositions in the $2 \theta$ range 42 - 50 degree.

calculated inter-planar spacing (d-values), suggests that the compositions are stabilized in rhombohedral phase. The unit cell is selected for which $\Sigma \Delta \mathrm{d}=\Delta\left(\mathrm{d}_{\mathrm{obs}}-\mathrm{d}_{\text {cal }}\right)$ is minimum. It can be seen from Figure 1 that the prepared compositions have pure phase without any detectable impurity phases. The lattice constants obtained for different compositions are shown in table 1 for rhombohedral and hexagonal unit cells. The estimated lattice parameters are very close to those obtained in earlier reports [28] [29] (JCPDF No-36-0340). Also Figure 1(b) shows the XRD patterns of the ceramics in the $2 \theta$ range of $44-50$ degree. A distinct 002/200 peak splitting appears when doping percentage changes from 0.02 to 0.03 , referring to a hexagonal symmetry. To characterize the phase compositions in a more quantitative way, the XRD patterns of the MPB compositions in the $2 \theta$ ranges of $46^{\circ}-48^{\circ}$ were fitted as shown in Figure 2. The data shows the Lorentzian deconvolution of the 002 and 200 peaks of the tetragonal phase and the 202 peak of the rhombohedral phase. These results suggest that the rhom- 


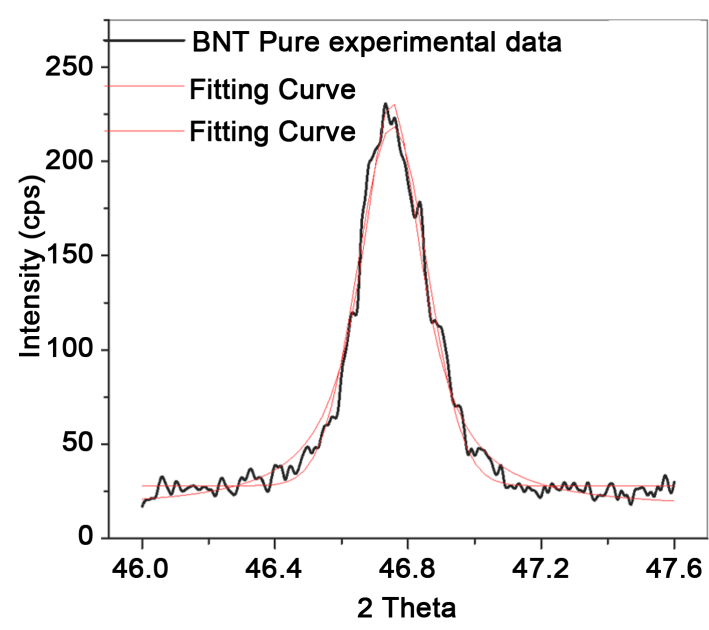

(a)

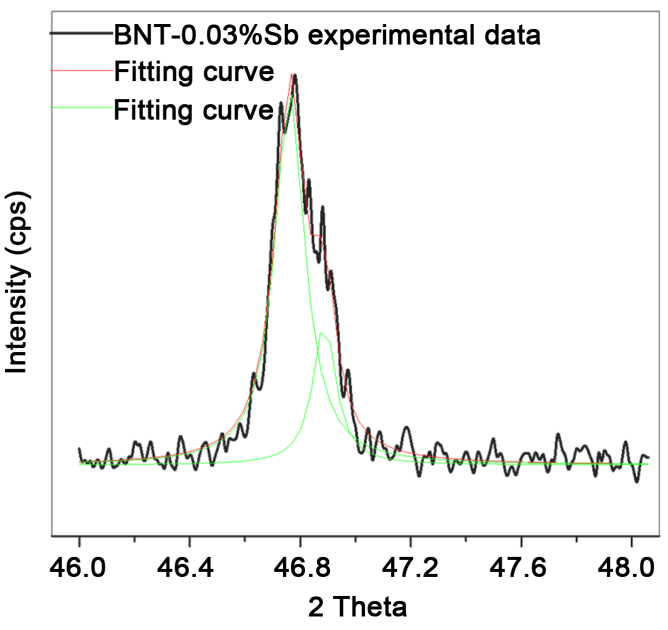

(b)

Figure 2. XRD fitting patterns of Sb doped BNT ceramics (a) $0 \%$ and (b) $0.03 \%$.

bohedral-hexagonal morphotrophic phase boundary (MPB) appears in ceramic near to doping level at $0.03 \% \mathrm{Sb}$ content.

\subsection{Raman Spectroscopic Analysis}

Figure 3 represents the Raman spectra of pure BNT and Sb doped BNT with different percentage. There are only five Raman-active modes observed in the range from 100 to $1000 \mathrm{~cm}^{-1}$ in agreement with earlier report [30] [31]. BNT ceramics with rhombohedral structure presents 13 Raman-active modes $\left(\Gamma_{\text {Raman }}=4 \mathrm{~A}_{1}+9 \mathrm{E}\right)$ due to the disorder in A-site related to distorted octahedral $\left[\mathrm{BiO}_{6}\right]$ and $\left[\mathrm{NaO}_{6}\right]$ clusters [32]. The first Raman active $\mathrm{A}_{1}$ $\left(\mathrm{TO}_{1}\right)$ mode at around $\left(144 \mathrm{~cm}^{-1}\right)$ is related to distorted octahedral $\left[\mathrm{BiO}_{6}\right]$ and $\left[\mathrm{NaO}_{6}\right]$ clusters. The second Raman active $\mathrm{E}\left(\mathrm{TO}_{2}\right)$ mode was observed in the regions of $276 \mathrm{~cm}^{-1}$ which is assigned to stretching arising from the bonds due to presence of octahedral $\left[\mathrm{TiO}_{6}\right]$ clusters at short-range.

The third Raman-active $\left(\mathrm{LO}_{2}\right)$ mode is related to short-range electrostatic forces associated with the lattice iconicity [33]. The $\left(\mathrm{TO}_{3}\right)$ mode situated at around $541 \mathrm{~cm}^{-1}$ may be due to the (O-Ti-O) stretching symmetric vibrations of the octahedral $\left[\mathrm{TiO}_{6}\right.$ ] clusters [34]. The $\left(\mathrm{LO}_{3}\right)$ mode found at $813 \mathrm{~cm}^{-1}$ is due to the presence of the sites within the rhombohedral lattice pre containing octahedral distorted $\left[\mathrm{TiO}_{6}\right]$ clusters [35]. There is no significant change in the spectra for the prepared compositions. For better observation of the Raman spectra of BNT pure and $\mathrm{Sb}$ doped $\mathrm{BNT}(\mathrm{Sb}=0.03 \%)$ along with the curves fitted to individual peaks are shown in Figure 4. The spectra of BNT $\left(\mathrm{Sb}=0.03 \%\right.$ ) shows additional peaks around 151, 281, 585 and $853 \mathrm{~cm}^{-1}$ compared to the peaks observed in BNT. The occurrence of these bands splitting may be due to structural change at doping level $0.03 \%$ of Sb, which are well in line with the studies of XRD phase analysis. However, from Figure 3 it is possible to detect that all the Raman peaks are very broad in BNT and Sb doped BNT ceramics. It is believed that this behaviour is due to the presence of the disorder structural or distorted octahedral $\left[\mathrm{TiO}_{6}\right]$ clusters at short-range and the overlapping of Raman modes due to the lattice anharmonicity.

For closer investigation, the variation of full width of half maximum (FWHM) and intensity of individual peaks are plotted in Figure 5(a) and Figure 5(b). The mode intensity and FWHM undergo slope change at Sb = 0.03. The variation of intensity and FWHM of all peaks shows a similar type of anomaly at $\mathrm{Sb}=0.03$. On the basis of these considerations, it is possible to conclude that the rhombohedral-tetragonal phase co-exists at $x=$ 0.03 which is also observed in the XRD results.

\section{Conclusion}

Pure and antimony doped BNT electro ceramics were successfully synthesized by a conventional solid state reaction route. X-ray diffraction analysis showed that a probable structural change at the $0.03 \% \mathrm{Sb}$ doped with the BNT. It may be possible that a morphotropic phase boundary (MPB) exists around $x=0.03$. Analysis of 


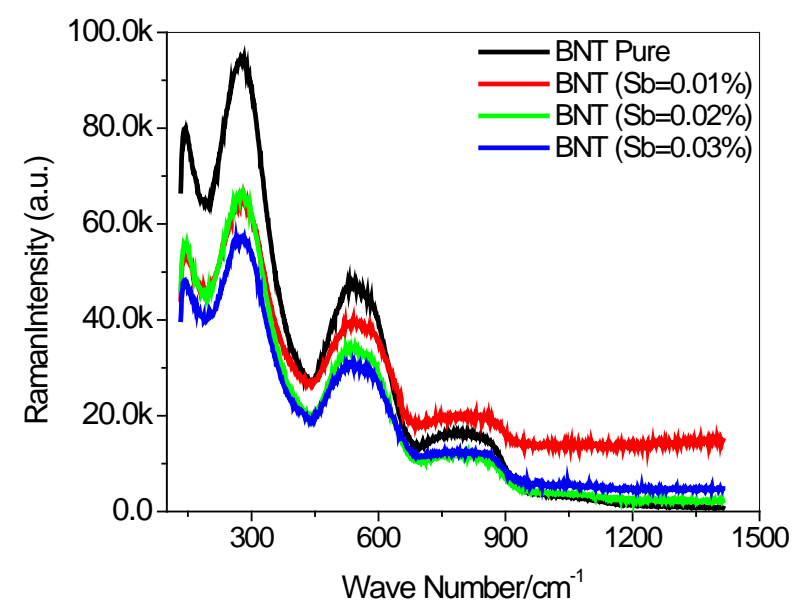

Figure 3. Raman spectra of Sb doped BNT ceramic with different compositions.

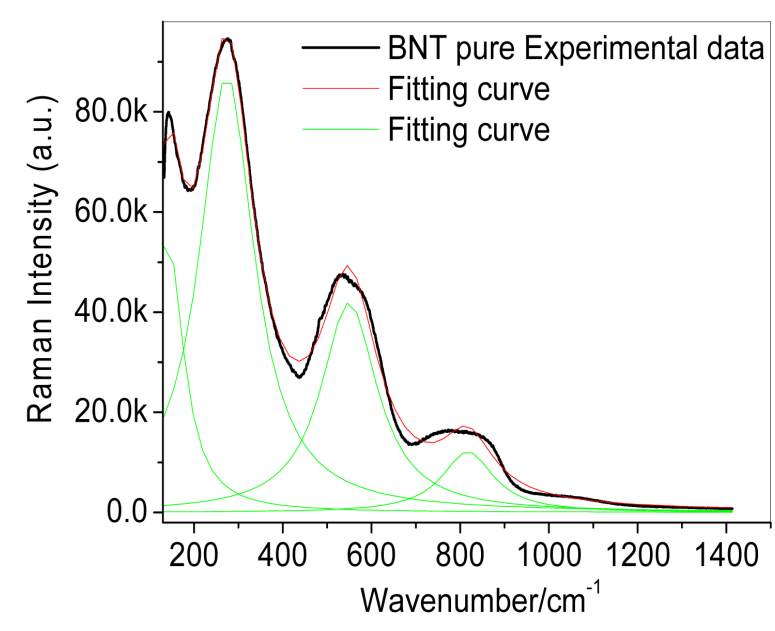

(a)

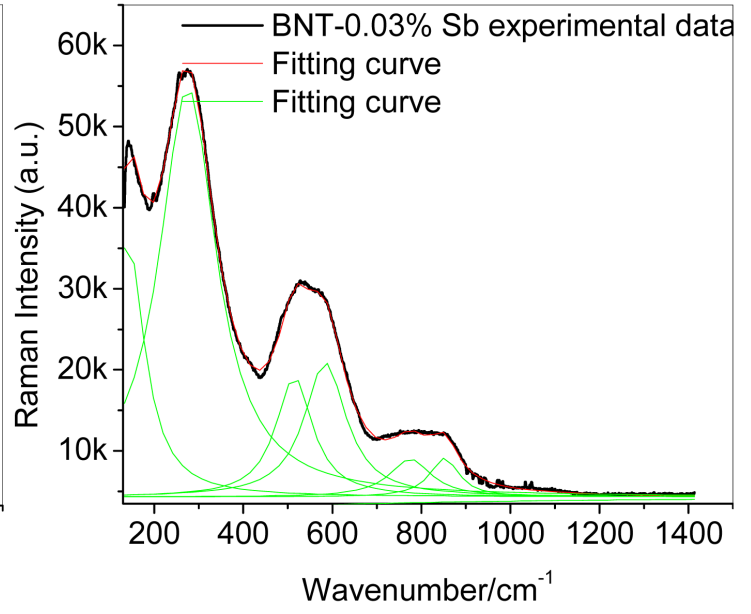

(b)

Figure 4. Raman spectra of BNT Black line is the experimental data and green lines are the fitting curve versus Sb concentration. (a) For pure BNT while (b) for BNT with $0.03 \%$ Sb.

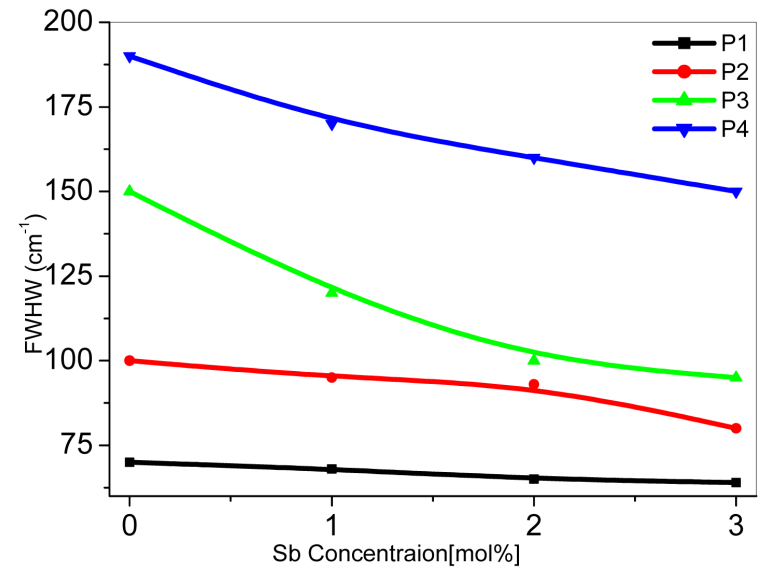

(a)

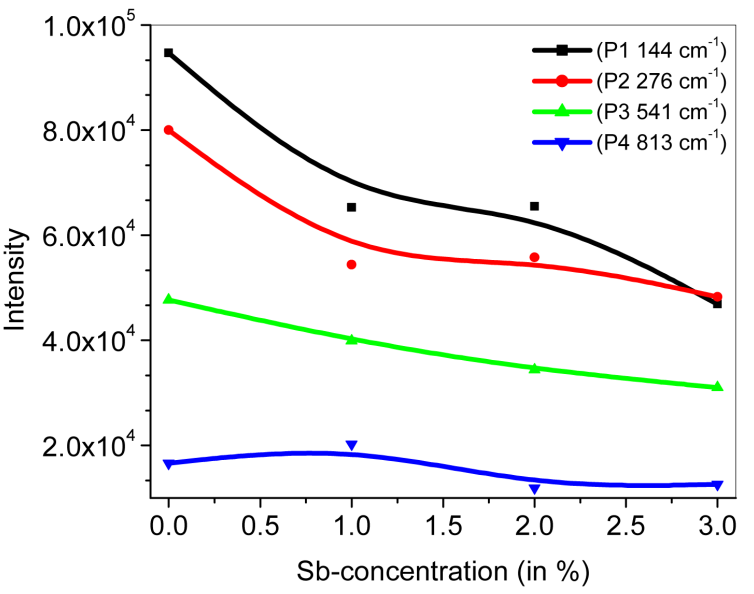

(b)

Figure 5. Variation of the FWHM and intensity of different modes in the Raman spectra versus Sb-concentration is shown in figure (a) and (b) respectively. 
peak positions, widths and intensities of Raman spectroscopy study also confirmed the existence of structural change around $x=0.03$ composition.

\section{References}

[1] Cross, L.E., Jang, S.J. and Newnham, R.E. (1980) Large Electrostrictive Effects in Relaxor Ferroelectrics. Ferroelectrics, 23, 187-191. http://dx.doi.org/10.1080/00150198008018801

[2] Nomura, S. and Uchino, K. (1983) Recent Applications of PMN-Based Electrostrictors. Ferroelectrics, 50, $197-202$. http://dx.doi.org/10.1080/00150198308014450

[3] Uchino, K. (2000) Ferroelectric Devices. Marcel Dekker, Inc., New York.

[4] Smolenski, G.A., Isupov, V.A. and Aganovskaya, A.I. (1961) J. Sov. Phys. Solid State, 2, 2651.

[5] Rupprecht, G. and Bell, R.O. (1964) Dielectric Constant in Paraelectric Perovskites. Physical Review, 135, A748. http://dx.doi.org/10.1103/PhysRev.135.A748

[6] Suchanicz, J., Poleder, K., Kania, A. and Handerek, J. (1988) Electrostrictive Strain and Pyroeffect in the Region of Phase Coexistence in $\mathrm{Na}_{0.5} \mathrm{Bi}_{0.5} \mathrm{TiO}_{3}$. Ferroelectrics, 77, 107-110. http://dx.doi.org/10.1080/00150198808223232

[7] Jones, G.O. and Thomas, P.A. (2002) Investigation of the Structure and Phase Transitions in the Novel A-Site Substituted Distorted Perovskite Compound $\mathrm{Na}_{0.5} \mathrm{Bi}_{0.5} \mathrm{TiO}_{3}$. Acta Crystallographica Section B, 58, 168-178. http://dx.doi.org/10.1107/S0108768101020845

[8] Suryanarayana, S.V., Raghavender, M., Prasad, G. and Bhimasankara, T. (2007) Material Science and Technology Conference (MS\&T).

[9] Park, S.E. and Hong, K.S. (1997) Variations of Structure and Dielectric Properties on Substituting A-Site Cations for $\mathrm{Sr}^{2+}$ in $\left(\mathrm{Na}_{1 / 2} \mathrm{Bi}_{1 / 2}\right) \mathrm{TiO}_{3}$. Journal of Materials Research, 12, 2152-2157. http://dx.doi.org/10.1557/JMR.1997.0288

[10] Sakata, K. and Masuda, Y. (1974) Ferroelectric and Antiferroelectric Properties of $\left(\mathrm{Na}_{0.5} \mathrm{Bi}_{0.5}\right) \mathrm{TiO}_{3}-\mathrm{SrTiO}_{3}$ Solid Solution Ceramics. Ferroelectrics, 7, 347-349. http://dx.doi.org/10.1080/00150197408238042

[11] Nagata, H. and Takenaka, T. (1997) Lead-Free Piezoelectric Ceramics of $\left(\mathrm{Bi}_{1 / 2} \mathrm{Na}_{1 / 2}\right) \mathrm{TiO}_{3}-1 / 2\left(\mathrm{Bi}_{2} \mathrm{O}_{3} \cdot \mathrm{Sc}_{2} \mathrm{O}_{3}\right) \mathrm{System}$. Japanese Journal of Applied Physics, 36, 6055-6057. http://dx.doi.org/10.1143/JJAP.36.6055

[12] Soukhojak, A.N., Wang, H., Farrey, G.W. and Chiang, Y.-M. (2000) Superlattice in Single Crystal Barium-Doped Sodium Bismuth Titanate. Journal of Physics and Chemistry of Solids, 61, 301-304. http://dx.doi.org/10.1016/S0022-3697(99)00297-8

[13] Sheets, S.A., Soukhojak, A.N., Ohashi, N. and Chiang, Y.-M. (2001) Relaxor Single Crystals in the $\left(\mathrm{Bi}_{1 / 2} \mathrm{Na}_{1 / 2}\right)_{1-\mathrm{x}^{-}}$ $\mathrm{Ba}_{x} \mathrm{Zr}_{y} \mathrm{Ti}_{1-\mathrm{y}} \mathrm{O}_{3}$ System Exhibiting High Electrostrictive Strain. Journal of Applied Physics, 90, 5287. http://dx.doi.org/10.1063/1.1410325

[14] Suchanicz, J., Gavshin, M.G., Kudzin, A.Y. and Kus, C. (2001) Dielectric Properties of $\left(\mathrm{Na}_{0.5} \mathrm{Bi}_{0.5}\right)_{1-x} \mathrm{Me}_{\chi} \mathrm{TiO}_{3} \mathrm{Ceram-}$ ics near Morphotropic Phase Boundary. Journal of Materials Science, 36, 1981-1985. http://dx.doi.org/10.1023/A:1017566412219

[15] Jaitanong, N., Vittayakorn, W.C. and Chaipanich, A. (2010) Phase Development and Dielectric Responses in PMNBNT Ceramics. Ceramics International, 36, 1479-1483. http://dx.doi.org/10.1016/j.ceramint.2010.01.003

[16] Yoshii, K., Hiruma, Y., Nagata, H. and Takenaka, T. (2006) Electrical Properties and Depolarization Temperature of $\left(\mathrm{Bi}_{1 / 2} \mathrm{Na}_{1 / 2}\right) \mathrm{TiO}_{3}-\left(\mathrm{Bi}_{1 / 2} \mathrm{~K}_{1 / 2}\right) \mathrm{TiO}_{3}$ Lead-Free Piezoelectric Ceramics. Japanese Journal of Applied Physics, 45, 44934496. http://dx.doi.org/10.1143/JJAP.45.4493

[17] Yang, Z., Hou, Y., Pan, H. and Chang, Y. (2009) Structure, Microstructure and Electrical Properties of $\left(1-\mathrm{x}^{-} \mathrm{y}\right) \mathrm{Bi}_{0.5^{-}}$ $\mathrm{Na}_{0.5} \mathrm{TiO}_{3}-x \mathrm{Bi}_{0.5} \mathrm{~K}_{0.5} \mathrm{TiO}_{3}-y \mathrm{Bi}_{0.5} \mathrm{Li}_{0.5} \mathrm{TiO}_{3}$ Lead-Free Piezoelectric Ceramics. Journal of Alloys and Compounds, 480, 246-253. http://dx.doi.org/10.1016/j.jallcom.2009.02.030

[18] Li, Y.M., Chen, W., Zhou, J., Xu, Q., Sun, H.J. and Xu, R.X. (2004) Dielectric and Piezoelecrtic Properties of Lead-Free $\left(\mathrm{Na}_{0.5} \mathrm{Bi}_{0.5}\right) \mathrm{TiO}_{3}-\mathrm{NaNbO}_{3}$ Ceramics. Materials Science and Engineering: $B, 112$, 5-9. http://dx.doi.org/10.1016/j.mseb.2004.04.019

[19] Lin, D., Xiao, D., Zhu, J. and Yu, P. (2006) Piezoelectric and Ferroelectric Properties of Lead-Free [Bi $\mathrm{Bi}_{1-y}\left(\mathrm{Na}_{1-x-y}{ }^{-}\right.$ $\left.\left.\mathrm{Li}_{x}\right)\right]_{0.5} \mathrm{Ba}_{y} \mathrm{TiO}_{3}$ Ceramics. Journal of the European Ceramic Society, 26, 3247-3251. http://dx.doi.org/10.1016/j.jeurceramsoc.2005.09.038

[20] Lin, D., Kwok, K.W. and Chan, H.L.W. (2009) Ferroelectric and Piezoelectric Properties of $\mathrm{Bi}_{0.5} \mathrm{Na}_{0.5} \mathrm{TiO}_{3}-\mathrm{SrTiO}_{3}-$ $\mathrm{Bi}_{0.5} \mathrm{Li}_{0.5} \mathrm{TiO}_{3}$ Lead-Free Ceramics. Journal of Alloys and Compounds, 481, 310-315. http://dx.doi.org/10.1016/j.jallcom.2009.02.120

[21] Shieh, J., Wu, K.C. and Chen, C.S. (2007) Switching Characteristics of MPB Compositions of $\left(\mathrm{Bi}_{0.5} \mathrm{Na}_{0.5}\right) \mathrm{TiO}_{3}-\mathrm{Ba}$ $\mathrm{TiO}_{3}-\left(\mathrm{Bi}_{0.5} \mathrm{~K}_{0.5}\right) \mathrm{TiO}_{3}$ Lead-Free Ferroelectric Ceramics. Acta Materialia, 55, 3081-3087. 
http://dx.doi.org/10.1016/j.actamat.2007.01.012

[22] Lin, D., Xu, C., Zheng, Q., Wei, Y. and Gao, D. (2009) Piezoelectric and Dielectric Properties of $\mathrm{Bi}_{0.5} \mathrm{Na}_{0.5} \mathrm{TiO}_{3^{-}}$ $\mathrm{Bi}_{0.5} \mathrm{Li}_{0.5} \mathrm{TiO}_{3}$ Lead-Free Ceramics. Journal of Materials Science: Materials in Electronics, 20, 393-397. http://dx.doi.org/10.1007/s10854-008-9741-y

[23] Xu, C., Lin, D. and Kwok, K.W. (2008) Structure, Electrical Properties and Depolarization Temperature of (Bi ${ }_{0.5}-$ $\left.\mathrm{Na}_{0.5}\right) \mathrm{TiO}_{3}-\mathrm{BaTiO}_{3}$ Lead-Free Piezoelectric Ceramics. Solid State Sciences, 10, 934-940. http://dx.doi.org/10.1016/j.solidstatesciences.2007.11.003

[24] David, L.W. and David, A.P. (2003) Microstructure Development in Reactive-Templated Grain Growth of $\mathrm{Bi}_{1 / 2} \mathrm{Na}_{1 / 2^{-}}$ $\mathrm{TiO}_{3}$-Based Ceramics: Template and Formulation Effects. Journal of the American Ceramic Society, 86, 769-774. http://dx.doi.org/10.1111/j.1151-2916.2003.tb03373.x

[25] Richard, J., Pettry, G., Said, S., Marchet, P. and Mercurio, J.P. (2004) Sodium-Bismuth Titanate Based Lead-Free Ferroelectric Materials. Journal of the European Ceramic Society, 24, 1165-1169. http://dx.doi.org/10.1016/S0955-2219(03)00473-4

[26] K.S. Rao, Rajulu, K.C.V., Tilak, B. and Swathi, A. (2010) Effect of Ba ${ }^{2+}$ in BNT Ceramics on Dielectric and Conductivity Properties. Nature Science, 2, 357-367.

[27] Wu, E. (1989) “POWD”, An Interactive Powder Diffraction Data Interpretation and Indexing Programme. Ver. 2.1, School of Physical Sciences, Flinders University of South Australia, Bedford Park, S.A., 5042, Australia.

[28] Peng, C., Li, J.-F. and Gong, W. (2005) Preparation and Properties of $\left(\mathrm{Bi}_{1 / 2} \mathrm{Na}_{1 / 2}\right) \mathrm{TiO}_{3}-\mathrm{Ba}(\mathrm{Ti}, \mathrm{Zr}) \mathrm{O}_{3}$ Lead-Free Piezoelectric Ceramics. Materials Letters, 59, 1576-1580. http://dx.doi.org/10.1016/j.matlet.2005.01.026

[29] Rachakom, A., Jiansirisomboon, S. and Watcharapasorn, A. (2009) Journal of Microscopy Society of Thailand, 23, 107.

[30] Rout, D., Moon, K.S., Kang, S.J.L. and Kim, I.W. (2010) Dielectric and Raman Scattering Studies of Phase Transitions in the $(100-x) \mathrm{Na}_{0.5} \mathrm{Bi}_{0.5} \mathrm{TiO}_{3}-\chi \mathrm{SrTiO}_{3}$ System. Journal of Applied Physics, 108, Article ID: 084102. http://dx.doi.org/10.1063/1.3490781

[31] Eerd, B.W.V., Damjanovic, D., Klein, N., Setter, N. and Trodahl, J. (2010) Structural Complexity of $\left(\mathrm{Na}_{0.5} \mathrm{Bi}_{0.5}\right) \mathrm{TiO}_{3^{-}}$ $\mathrm{BaTiO}_{3}$ as Revealed by Raman Spectroscopy. Physical Review B, 82, Article ID: 104112. http://dx.doi.org/10.1103/PhysRevB.82.104112

[32] Petzelt, J., Kamba, S., Fabry, J., Noujni, D., Porokhonskyy, V., Ashkin, A., Franke, I., Roleder, K., Suchanicz, J., Klein, R. and Kugel, G.E. (2004) Infrared, Raman and High-Frequency Dielectric Spectroscopy and the Phase Transitions in $\mathrm{Na}_{1 / 2} \mathrm{Bi}_{1 / 2} \mathrm{TiO}_{3}$. Journal of Physics: Condensed Matter, 16, 2719-2731. http://dx.doi.org/10.1088/0953-8984/16/15/022

[33] Chaves, A., Katiyar, R.S. and Porto, S.P.S. (1974) Coupled Modes with $A_{1}$ Symmetry in Tetragonal BaTiO ${ }_{3}$. Physical Review B, 10, 3522-3533. http://dx.doi.org/10.1103/PhysRevB.10.3522

[34] Domenico Jr., M.D., Wemple, S.H., Porto, S.P.S. and Buman, P.R. (1968) Raman Spectrum of Single-Domain BaTiO . $^{2}$ Physical Review, 174, 522-530.

[35] Sczancoski, J.C., Cavalcante, L.S., Badapanda, T., Rout, S.K., Panigrahi, S., Mastelaro, V.R., Varela, J.A., Li, M.S. and Longo, E. (2010) Structure and Optical Properties of $\left[\mathrm{Ba}_{1-x} \mathrm{Y}_{2 \times / 3}\right]\left(\mathrm{Zr}_{0.25} \mathrm{Ti}_{0.75}\right) \mathrm{O}_{3}$ Powders. Solid State Sciences, 12, 1160-1167. http://dx.doi.org/10.1016/j.solidstatesciences.2010.04.002 